\title{
Scandinavian Social Values, Attitudes and Young People’s Entrepreneurial Intention: A Finnish Contribution*
}

\author{
Teemu Rantanen \\ Laurea University of Applied Sciences, Vantaa, Finland \\ Timo Toikko \\ Seinäjoki University of Applied Sciences, Seinäjoki, Finland
}

\begin{abstract}
In this study, young people's attitudes towards entrepreneurship are examined in the Helsinki-Uusimaa region of Finland. The theoretical framework of the study links with attitude research, in particular Ajzen's theory of planned behavior. The second perspective is based on discussions of the welfare state and social values. In the study, it is asked what social psychological factors explain young people’s entrepreneurial intentions. Survey data $(N=873)$ were collected in electronic format from secondary and vocational schools. The questions were based on a multiple-choice Likert-scale. The analysis was undertaken using statistical methods, especially regression analysis. The results are mainly consistent with the theory of planned behavior: subjective norms and perceived control explain entrepreneurial intention. However, dependence between general entrepreneurial attitudes and entrepreneurial intention is not significant. The results demonstrate that there is no relation between social values and entrepreneurial intention in the Finnish context. Typically in social sciences, entrepreneurial discourse is linked to neo-liberal policy but, according to this study, entrepreneurship is a neutral issue among Finnish young people.
\end{abstract}

Keywords: attitudes, entrepreneurial intention, entrepreneurship, Scandinavian welfare state, social values, theory of planned behavior

\section{Introduction}

Scandinavian countries have emphasized a welfare policy which is based on the linchpin role of the state. Politically and culturally, Finland is a Scandinavian country even though geographically it does not belong to Scandinavia. As a welfare state, Finland is ranked high among the world leading countries in studies on living conditions and well-being, determined by factors such as education and health care, quality of life, economic dynamism, and the political environment.

In Finnish political discourse, entrepreneurship has become increasingly emphasized throughout the 21st century. Entrepreneurial activity is seen as a prerequisite for creating new jobs, as well as for national competitiveness. In many statements, entrepreneurship has been seen as a solution for the challenges of both regional viability and the employment of individuals. There are various kinds of programs to support innovative

\footnotetext{
* This article is part of the "Enhancing Young Entrepreneurship in the Finnish Uusimaa Region EER 2012” project. The research is funded by European Social Fund.

Teemu Rantanen, Ph.D., Adjunct Professor, Vantaa Unit, Laurea University of Applied Sciences.

Timo Toikko, Ph.D., Adjunct Professor, School of Health Care and Social Work, Seinäjoki University of Applied Sciences.

Correspondence concerning this article should be addressed to Teemu Rantanen, Laurea, Ratatie 22, 01300 Vantaa, Finland.

E-mail: teemu.rantanen@laurea.fi.
} 
opportunities for businesses and entrepreneurship has become a core part and task of Finnish politics.

In spite of economic success, the entrepreneurial intention of the Finnish adult population is lower than many other European countries (Stenholm, Heinonen, Kovalainen, \& Pukkinen, 2011). According to the Flash Eurobarometer 283 (2009), Finnish people's interest towards entrepreneurship has increased throughout the 2000s, but if the majority of Finns had a free choice, they would rather work as employees than entrepreneurs. This article focuses on the question: What factors explain the low willingness to undertake entrepreneurship among young people?

Young people's entrepreneurial willingness has been studied from many viewpoints. The perspective is often associated with entrepreneurship education and promotion. Different explanatory models have been developed, which are based on various psychological factors and also external variables. Social psychological models have also examined the environment's normative expectations. In some studies, entrepreneurial attitudes and intention have been examined from the perspective of cultural values, for example, individualism (Liñán \& Chen, 2009). Contrary to this however, there has been little research on the impact of societal social values on young people's entrepreneurial intention. In this study, the aim is to integrate both the social psychology and social values perspectives.

\section{Scandinavian Social Values}

Scandinavian social values can be seen as a compromise between individualism and collectivism, on the other hand, also as a reconciliation of values concerning social security and freedom (Patomäki, 2007).

The Scandinavian collectivism is based on an institutionalised societal system, which can be called the "Nordic Welfare State" (Esping-Andersen, 1990; Ervasti et al., 2008). The term "Nordic Welfare State" can refer to a broad social political system (Alestalo \& Kuhnle, 1987; Alestalo, Hort, \& Kuhnle, 2009). The state has a central role as the guarantor and producer of welfare, which stresses the standpoint of advancing the common good and support to less advantaged people. It strives to achieve a good society by providing everyone equal opportunities for education and health care amongst other things, regardless of people's geographical or social reference group. The Nordic Welfare State (including Finland), is grounded on the notion of universal welfare services (Anttonen \& Sipilä, 2012; compare Kuivalainen \& Niemelä, 2010). In this sense, the objective of the Scandinavian welfare state is to produce social security (Ervasti, 2012; Jensen, 2008; compare Rauch, 2007).

As well as societal responsibility, Scandinavian values are also based on individualism. In international comparisons, Finland is defined as an individualistic society (The Hofstede Centre, 2013). The concept of individualism is defined in many ways. Hofstede's (1980) classical analysis assumes that individualism and collectivism are opposites of each other. In contrast for example, Singelis et al. (1995) examine them as separate dimensions and make a difference between two forms of individualism. Horizontal individualism includes the conception of an autonomous individual and an emphasis on equality, whilst vertical individualism accepts inequality and the competition between individuals.

Horizontal individualism emphasizes democratic rights, which are based on equality (class, gender, and race). In this sense, individualism means the right to participate in social life and societal decision making as a full citizen and horizontal individualism can be linked to social justice. On the other hand, vertical individualism emphasizes an individual's sovereignty, and individualists are chiefly concerned with protecting individual autonomy against those obligations imposed by social institutions (such as the state). According to 
this framework, Finnish individualism can be classified as horizontal.

Typically, vertical individualism is seen to be more deeply linked to entrepreneurship than horizontal individualism (Lindsay, 2005). Vertical individualism accepts the inequality and competition between individuals which forms a kind of ideological basis for entrepreneurship. In the Finnish case this may explain the low willingness of entrepreneurship among young people. Even though the Finnish economy has been following the trends of neoliberalism, the Scandinavian values do not support the ideas of vertical individualism. Similarly, according to Patomäki (2007), although Finland has followed the neoliberal trend in economy, hardly anyone amongst the population is a self-declared neoliberal. The majority of Finns still believe in the Scandinavian welfare state and the principle of collective responsibility inherent to it (Ervasti, 2012).

\section{Attitudes Towards Entrepreneurship: Conceptual Analysis}

The key concept of this study is entrepreneurial intention, which means the young person's intention to work as an entrepreneur in the future. Intent is not only connected with the desire to work as an entrepreneur, but also their aspiration towards entrepreneurship. In a conceptual sense, it is also a different thing to talk about the future long-term plans on the one hand and of any concrete intention on the other hand. For instance, according to Paakkunainen's (2007, p. 71) results, although 69\% of Finnish young people considered setting up their own enterprises later in life, but only $2.6 \%$ had serious plans to do so in the near future.

In this study, entrepreneurial intention is not approached only from the perspective of social values, but also in regard to theoretical attitude. The concept of attitude can be understood in different ways, however almost all definitions of attitude highlight that an attitude always has a target that is valued in some dimension (Eagly \& Chaiken, 1993). Attitude is often understood as a personal trait or behavioral tendency. It may also be seen as a social and contextual concept (de Rosa, 1993). In practice, people's entrepreneurial attitudes are constructed in an intense interaction with the immediate environment, as well as societal circumstances and social values.

There are also different views of understanding the concept of entrepreneurial attitude. First of all, it can be talked about the general attitude, which is characterized by the entrepreneurial activity of successful entrepreneurs. Often, this kind of attitude is interpreted in terms of an individual's personality attributes. According to traditional entrepreneurial orientation theory, such properties are a willingness to take risk, innovativeness, and proactivity (Covin \& Slevin, 1991), as well as competitiveness and independence (Lumpkin \& Dess, 1996). However, there are problems with this kind of trait theoretical approach as it does not take into account the individual's own goals and values, nor the importance of the social environment.

Secondly, it can be talked about attitudes which target entrepreneurship as a general mind. In traditional attitude research, attitude is typically understood in this sense. However, several social psychological studies have shown that there is a quite poor correspondence between attitudes and external behavior. General attitudes do not explain behavior in specific situations. Ajzen and Fishbein (2000, pp. 16-17) argue that all activity takes a place within a context, and we have to particularly examine specific attitudes in light of such activity. An address of specific attitudes may explain and predict behavior much better than a consideration of general attitudes.

According to the theory of planned behavior, behavioral intention is impacted by three components: attitude towards behavior; subjective norm; and perceived behavioral control (Ajzen, 1991, p. 182). Thus, 
young people's entrepreneurial intention is influenced by their personal appreciations of entrepreneurship, the expectations of their closest circle and a person's own perception of their capacity as an entrepreneur. In this case, subjective norm means a belief of how people in one's closest circle evaluate the acceptability of certain behavior. The individual perspective of the social norm may be the perceived normative expectations of the parents, peer group, or professional field. In previous Finnish entrepreneurial education studies, it has been found that in particular, the support of parents for entrepreneurial activity is low. According to Kivelä's (2002) research, only $20 \%$ of Finnish parents estimated that their children had been encouraged to become entrepreneurs by their families.

A perceived behavioral control is connected with how a young person estimates his own personal capacity to endure the different duties and responsibilities associated with entrepreneurial activities and setting up an enterprise. The concept is based on Bandura's (1982) social learning theory and its concept of perceived self-efficacy. Bandura analyzed separately, control related to behavior and control related to outcome. The concept outcome expectation, means how firmly young people believe they can succeed as an entrepreneur. In addition to behavioral control, the outcome expectation is affected by many external factors.

The theory of planned behavior has proven to be effective when explaining entrepreneurial intention and behavior (Liñán, 2008; Liñán \& Chen, 2009; Goethner et al., 2012), as well as when used to assess entrepreneurship education programs (Fayolle et al., 2006). Moreover, the theory of planned behavior has been used as the basis for seeking ways to further develop new explanation models of entrepreneurial intention (Krueger, Reilly, \& Carsrud, 2000). However, there is a fundamental problem connected to Ajzen's (1991) conception of attitude: if all behaviors are linked with its own attitude, the concept of attitude becomes too narrow and its explanatory importance decreases. Indeed, this kind of attitude differs from the traditional concept of attitude. Some social psychologists have even suggested that the concept of attitude should even be rejected because of these problems (Potter \& Wetherell, 1987).

Our solution is that we replace Ajzen's (1991) conception of attitude with a general concept of attitude. This of course means that at the same time the dependence between attitude and behavior is reduced. In this study, we also assume that attitude is a contextual concept, not a personality trait. In particular, we look at the importance of social values in terms of entrepreneurial intention.

\section{Questions and Hypotheses}

The study targeted the Uusimaa region in Southern Finland. Geographically, Uusimaa covers only 3\% of Finland's land surface, but from a population and industrial production viewpoint, it represents approximately 33\% of Finland. The Uusimaa region consists of the Helsinki Metropolitan Area (about one million people) and the surrounding region of smaller cities and rural areas. We ask: What factors explain the low willingness to engage in entrepreneurship among young people in Uusimaa in Finland?

First, the entrepreneurial intentions of the Uusimaa students are examined: How attractive do young people find the option of entrepreneurship? How big a segment of young people intend to become entrepreneurs?

Also some of the background variables are examined, such as school (high school or vocational school), field of study, and entrepreneurial family (whether or not one of the parents or another family member is an entrepreneur). Our hypothesis is:

H1: Entrepreneurial intention depends on school, field of study, and entrepreneurial family history. 
Second, the research examines the subjective norms and perceived behavior following Ajzen's theory. The researched hypothesis is:

H2: Entrepreneurial intention depends on entrepreneurial attitude, social norms, and perceived control.

The third research target is social values or, more specifically, Scandinavian social values among Finnish students. Previous studies have shown that there is a connection between individualism and entrepreneurial attitudes or entrepreneurial intention (Mueller \& Thomas, 2000; Kreiser et al., 2001; Lindsay, 2005; Liñán \& Chen, 2009). However, this study is focused on Scandinavian social values, not individualism. In the study we asked: How strong is the correspondence between the Scandinavian social values and entrepreneurial intentions, and what is the connection between Scandinavian social values and other influencing factors? The hypotheses are:

H3: Entrepreneurial intention depends on Scandinavian social values.

H4: Entrepreneurial attitude, subjective norms, and perceived control depend on Scandinavian social values.

The main research design is shown in Figure 1.

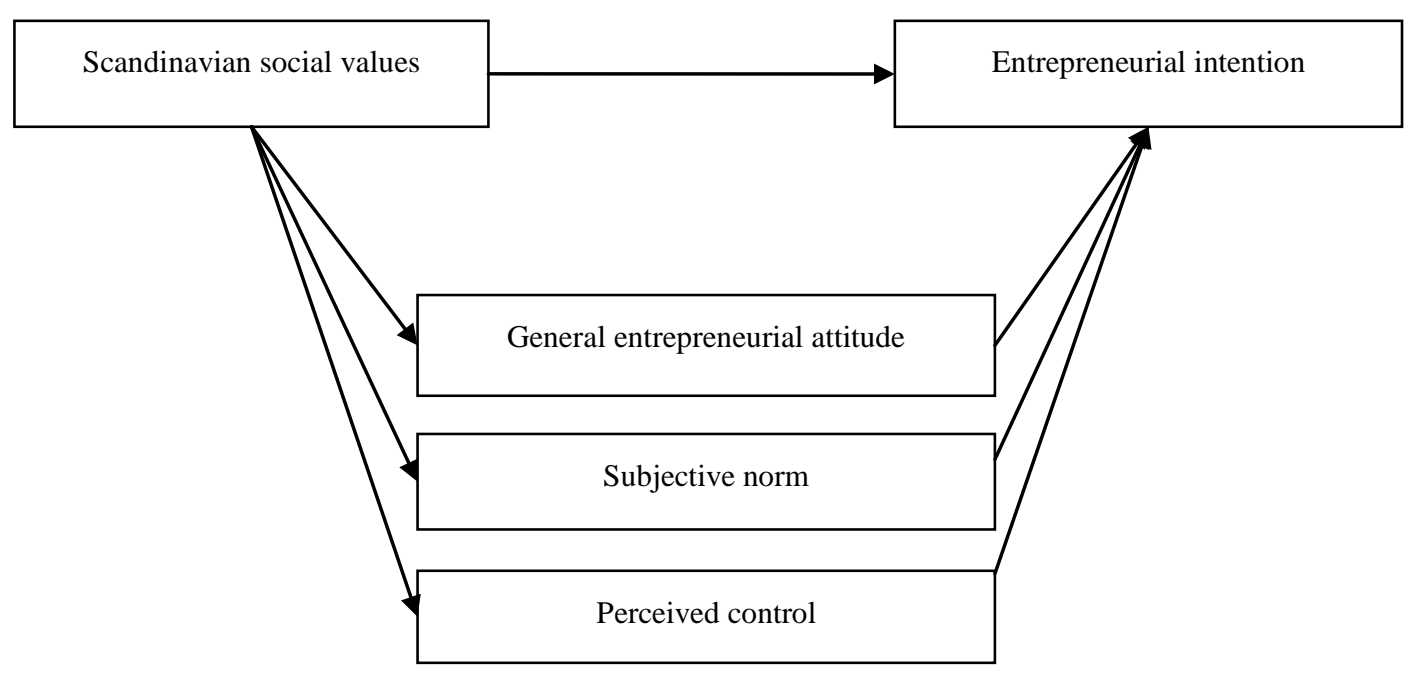

Figure 1. Research design.

\section{Method and Sample}

The data were collected by electronic questionnaire during Uusimaa students' class hours in January-February 2012. The respondents were students in high school and vocational school, and thus mainly 17-18 years of age. The sample is regionally comprehensive, and contained six high schools and seven vocational institutions or their units in the Uusimaa region. The sample includes general high schools, high schools specialized in creative fields (media, performing arts, and music), and vocational institutions in the fields of culture, business economics, social, and health care, as well as in the fields of technology and transport (Rantanen, 2013).

In composing the questionnaire, previous studies were used as a guide, but their specific questions were not used in this study. The questionnaire consisted of 72 questions that were composed mainly of Likert-type scale items ( 1 = Strongly disagree ... 5 = Strongly agree). The questions connected to the respondents' 
background information, entrepreneurial intention, entrepreneurial attitudes, subjective norms, perceived behavioral control, outcome expectancy, and social values. The form was pre-tested with 19 students. On the basis of the testing, only minor changes were made to the form.

Each studied quality was examined through four to five questions, sum variables were constructed using factor analysis (generalized least squares, Varimax with Kaiser normalization) and means, and then their reliabilities were calculated (Cronbach's alpha). The normality of the distribution was examined by using the Kolmogorov-Smirnov test and histograms. The explanatory model was examined by using linear regression analysis, and the correlation was calculated by the Spearman's correlation coefficient. The differences between groups were examined by using Kruskal-Wallis's variance analysis and $t$-test.

The representativeness of the survey turned out to be quite good: $71.1 \%$ of the respondents were from the Helsinki Metropolitan Area (68.4\% in the population), and the remainder were from other areas of the Uusimaa region. In our data, the share of Swedish-speaking respondents is a little lower than the overall population (6.8\% in our data and $8.6 \%$ in the population). The share of vocational school students $(47.2 \%)$ is close to the national proportion (45.2\%), but larger than in the big cities in the Helsinki Metropolitan Area (Helsingin kaupungin tilastokeskus, 2009; Statistics Finland, 2013). The survey’s average response rate was 71.0\% (high schools: 79.1\%; vocational schools: 63.7\%). The lower response rate among vocational school students was affected by school absence and the students' work practice periods.

During the survey, no unexpected problems arose concerning the questionnaire form, its questions, or its administration. Electronic data collection was well suited to the target group. The measures also turned out to be mainly functional and the reliabilities were relatively good. However, there were some problems concerning the distribution of variables, as not all of them corresponded with the normal distribution.

\section{Entrepreneurial Intention}

Entrepreneurial intention was examined by using four questions. The questions concern not only an actual intention to become an entrepreneur, but also the approximated probability for it to occur, as well as how desirable the option of entrepreneurship was in comparison to working as an employee (see Table 1).

Table 1

Questions Concerning Entrepreneurial Intention $(N=873)$

\begin{tabular}{lllll}
\hline Question & Agree \% & Disagree \% & Mean & S.D. \\
\hline 55. If I could freely choose, I would rather be an entrepreneur than an employee & 34.0 & 38.3 & 2.95 & 1.25 \\
59. My aim is to become an entrepreneur in the future & 18.8 & 48.9 & 2.53 & 1.17 \\
63. I am going to make a living as an entrepreneur & 13.6 & 49.1 & 2.42 & 1.12 \\
67. For me, entrepreneurship is a probable career choice & 17.1 & 51.3 & 2.45 & 1.16 \\
\hline
\end{tabular}

This result shows that Finnish students' willingness to become entrepreneurs is relatively low. The results also show that there is a difference in expressing entrepreneurial willingness depending on how the question is worded. The result is consistent with previous Finnish studies (e.g., Paakkunainen, 2007, p. 71). If we analyze the questions that are directly related to intention, fewer than $20 \%$ of the respondents agree and about half of the respondents disagree. The results are similar to previous studies. For example, the international Global Entrepreneurship Monitor research (Stenholm et al., 2011) showed that the Finns' entrepreneurial willingness was at quite a low level. The result is also consistent with the Flash Eurobarometer (2009) survey, according to which most Finnish people, if they were free to choose, would rather be an employee than an entrepreneur. 
A sum variable of entrepreneurial intention was formed based on these four questions. Though a probability assessment does not reveal intentions in a conceptual sense, Question 67 ("I trust I would be able to cope with the issues connected to setting up an enterprise”) was included in entrepreneurial intention because it strongly correlated with other variables of entrepreneurial intention. The reliability of this variable was good (alpha $=0.899$ ), but the distribution deviates slightly from the norm.

Next, the differences in entrepreneurial intention between the different groups of respondents were analyzed. Vocational school students and high school students (upper secondary school) did not differ from each other. On the other hand, there are perceptible differences in the entrepreneurial intention depending on the field of study $(Z=4.415 ; p=0.001)$. Especially noted is that the entrepreneurial intention among students in creative fields is significantly higher than in other fields (see Table 2).

Table 2

Entrepreneurial Intention and Social Background

\begin{tabular}{|c|c|c|c|c|c|}
\hline & & $N$ & Mean & S.D. & $t$ (sign.) \\
\hline & Yes & 286 & 2.90 & 1.05 & \\
\hline \multirow[t]{3}{*}{ Entrepreneurial family } & & & & & $6.472(p=0.000)$ \\
\hline & No & 587 & 2.43 & 0.99 & \\
\hline & High school & 464 & 2.57 & 1.00 & \\
\hline \multirow[t]{3}{*}{ School } & & & & & $-0.572(p=0.568)$ \\
\hline & $\begin{array}{l}\text { Vocational } \\
\text { school }\end{array}$ & 409 & 2.61 & 1.06 & \\
\hline & $\begin{array}{l}\text { Creative } \\
\text { field }\end{array}$ & 222 & 2.86 & 0.99 & \\
\hline \multirow[t]{2}{*}{ Field of education } & & & & & $4.674(p=0.000)$ \\
\hline & Other field & 651 & 2.49 & 1.03 & \\
\hline All & & 873 & 2.59 & 1.03 & - \\
\hline
\end{tabular}

About one-third of respondents came from an entrepreneurial family, which meant that one of the parents or another family member was an entrepreneur. However, only $2.6 \%$ expressed the probability that they would continue the family's entrepreneurial activities. It was seen that entrepreneurial intention depends significantly on the family history of young people, in that entrepreneurial intention is higher among those respondents with an entrepreneurial family background.

Thus, Hypothesis 1 is only partially valid. Entrepreneurial intention depends on the field of study and entrepreneurial family history, but the difference between schools (high school, vocational school) is not significant.

\section{General Entrepreneurial Attitude, Norms, and Perceived Control}

Next, we sought a model that would explain the entrepreneurial intention as well as the possibility for its occurrence. At first the variables were examined by using factor analysis, and then this was used to examine the issues related to general entrepreneurial attitude, subjective norms, perceived behavioral control, and control of outcomes. A three-factor model is shown in Table 3. 
Table 3

Questions Concerning General Entrepreneurial Attitude, Subjective Norms, Perceived Behavioral Control, and Control of Outcomes: Factor Analysis, Three Factors, Loadings Over 0.4 (Generalized Least Squares, Varimax With Kaiser Normalization)

\begin{tabular}{|c|c|c|c|}
\hline & Factor 1 & Factor 2 & Factor 3 \\
\hline 27. Entrepreneurs are ideal citizens & - & - & 0.541 \\
\hline 31. Entrepreneurs are typically hard-working and responsible & - & - & 0.572 \\
\hline 35. Entrepreneurs' work is valuable for the entire society & - & - & 0.760 \\
\hline 39. Entrepreneurs play a key role in the success of society & - & - & 0.650 \\
\hline 56. My close environment encourages me towards entrepreneurship & - & 0.717 & - \\
\hline 57. I trust I am capable of working as a small entrepreneur & 0.818 & - & - \\
\hline 58. I believe I could succeed as an entrepreneur & 0.841 & - & - \\
\hline $\begin{array}{l}\text { 60. In my field (or my desired professional field), entrepreneurship is a valued } \\
\text { career option }\end{array}$ & 1 & 0.430 & - \\
\hline 61. I believe I could learn the skills required for entrepreneurship & 0.673 & - & - \\
\hline 62.I believe I could make a living as an entrepreneur & 0.763 & - & - \\
\hline 64. My parents encourage me towards entrepreneurship & - & 0.820 & \\
\hline $\begin{array}{l}\text { 65. I trust I would be able to cope with the issues connected to setting up an } \\
\text { enterprise }\end{array}$ & 0.761 & - & - \\
\hline 66. Succeeding as an entrepreneur is not too challenging for me & 0.698 & - & \\
\hline 68. My friends would find it great if I became an entrepreneur & - & 0.514 & - \\
\hline $\begin{array}{l}\text { 69. I believe I would have the qualifications to work as the manager of a small } \\
\text { enterprise }\end{array}$ & 0.705 & - & - \\
\hline
\end{tabular}

In this model, the "perceived behavioral control" and the "control of outcomes" combine at the same factor, and the correlations between them are so great that there is no reason to consider them separately. Factor 1 contains questions concerned with a respondent's self-belief about being able to cope with working as an entrepreneur, as well as to succeed as an entrepreneur. Based on factor 1, the sum variable perceiver control was formed, and it includes seven issues.

Secondly, the sum variable "subjective norms" was formed based on factor 2. It contains four questions that connect to the expectations and desires in a respondent's close environment. Issues relate to the view of the peer group, parents, and the respondent's study field. Finally, we constructed the sum variable "general entrepreneurial attitude" from the four questions that loaded most highly in factor 3 . The questions concerned an entrepreneur's ethics of hard work and responsibility, as well as the societal significance of an entrepreneur's work.

Table 4 shows the mean, standard deviations, and reliabilities of these sum variables. The alpha coefficient of the perceived control is very good, and two other reliabilities are seen at a reasonable level.

The theory of planned behavior argues that intention can be explained by attitude, subjective norms, and perceiver behavioral control. The attitude towards the respondents' own activity is replaced by a general attitude, and perceived behavioral control by perceived control. The model was analyzed using regression analysis.

According to the Kolmogorov-Smirnov test, the distribution of residuals is not perfectly normal; however, graphical analysis indicates that the distribution is close to normal. The other conditions of linear regression analysis (especially independence and linearity) are satisfied. Results are reported in Table $5(F(3,868)=439.5$; $p=0.000$ ). This model's explained variance was $60.2 \%$. 
Table 4

General Entrepreneurial Attitude, Subjective Norms, and Perceived Control

\begin{tabular}{llllll}
\hline & $N$ & Items & $\begin{array}{l}\text { Cronbach's } \\
\text { alpha }\end{array}$ & Mean & S.D. \\
\hline General entrepreneurial attitude & 872 & 4 & 0.740 & 3.60 & 0.65 \\
Subjective norm & 873 & 4 & 0.781 & 2.77 & 0.86 \\
Perceived control & 873 & 7 & 0.924 & 3.28 & 0.91 \\
\hline
\end{tabular}

Table 5

Regression Analysis (Unstandardized B-coefficients, Standardized Beta-coefficients and Significances)

\begin{tabular}{lllllll}
\hline & B & S.D. & Beta & \multicolumn{1}{l}{ sign. } & VIF \\
\hline (constant) & -0.332 & 0.132 & - & -2.521 & 0.012 & - \\
General entrepreneurial attitude & -0.036 & 0.036 & -0.023 & -1.005 & 0.315 & 1.142 \\
Subjective norm & 0.647 & 0.032 & 0.538 & 20.249 & 0.000 & 1.546 \\
Perceived control & 0.384 & 0.030 & 0.338 & 12.623 & 0.000 & 1.563 \\
\hline
\end{tabular}

Thus, Hypothesis 2 is only partially valid. The analysis shows that the subjective norms explain entrepreneurial intention very well. Also, the beta coefficient of perceived control is quite high. In the case of general entrepreneurial attitude, the $t$-value is not significant. As such, it can be concluded that a general attitude alone does not predict the desire to become an entrepreneur. From the perspective of attitude theory, this result is not totally unexpected. Many previous studies have shown that general attitudes are not really able to predict the behavior of the individual.

\section{Scandinavian Social Values and Entrepreneurial Intention}

Next, the questions concerning social values are examined. Some issues related to the individual's democratic rights will be studied, such as the freedom of the individual and the rights of the citizen. We will also study some of the questions related to the value base of the Nordic welfare state. These issues emphasize a common responsibility and the significance of the public sector (see Table 6).

Table 6

Questions Concerning Scandinavian Social Values: Democratic Rights (Issues 44, 47, and 50) and Social Justice (Issues 43, 46, and 52)

\begin{tabular}{|c|c|c|c|c|c|}
\hline Question & $N$ & Agree \% & Disagree \% & Mean & S.D. \\
\hline $\begin{array}{l}\text { 44. Western democracy is an essential value in } \\
\text { our society }\end{array}$ & 872 & 63.9 & 3.6 & 3.86 & 0.881 \\
\hline $\begin{array}{l}\text { 47. Individual freedom is one of the core values in } \\
\text { our society }\end{array}$ & 872 & 80.4 & 3.0 & 4.24 & 0.870 \\
\hline 50. Civil rights is the foundation of our society & 873 & 77.5 & 3.1 & 4.14 & 0.860 \\
\hline $\begin{array}{l}\text { 43. Society's mission is to guarantee the } \\
\text { well-being of all citizens }\end{array}$ & 873 & 84.7 & 6.1 & 4.30 & 0.937 \\
\hline $\begin{array}{l}\text { 46. Society should ensure that no one becomes } \\
\text { socially excluded }\end{array}$ & 872 & 74.9 & 7.5 & 4.06 & 0.970 \\
\hline 52. Equality and justice are key social objectives & 872 & 78.0 & 5.5 & 4.16 & 0.929 \\
\hline
\end{tabular}

The results show that Finnish young people's attitudes towards Scandinavian social values are very positive. The respondents related positively to both an individual's democratic rights and social to justice (Muuri, 2008). Opinions were most strongly divided by the claim "Western democracy is a core value in our society": $64 \%$ of respondents agreed with the claim and one-third took a neutral stand. It can be assumed that 
the abstract quality of the concept of Western democracy explains the multitude of neutral responses to this question. In regard to the rest of the questions, $75 \%-85 \%$ of respondents agreed with each one.

On the basis of these six questions, the sum variable "Scandinavian social values" was formed $(N=873$; Mean $=4.12$; S.D. $=0.65$ ). The reliability of the variable (Cronbach's alpha) is 0.811 . The correlation between Scandinavian social values and entrepreneurial intention is not significant. The correlations between Scandinavian social values and other sum variables are shown in Table 7.

Table 7

Variables’ Correlations With Scandinavian Social Values

\begin{tabular}{llcl}
\hline & $N$ & Spearman's rho & sign., two-tailed \\
\hline General entrepreneurial attitude & 872 & 0.298 & 0.000 \\
Subjective norm & 873 & -0.044 & 0.195 \\
Perceived control & 873 & 0.093 & 0.006 \\
Entrepreneurial intention & 873 & -0.058 & 0.088 \\
\hline
\end{tabular}

Table 7 shows that there is a strong interdependence between Scandinavian social values and general entrepreneurial attitude. This was expected, as in Finnish culture, entrepreneurs have often been seen as responsible and as ideal citizens. However, according to the results, this positive perception of an entrepreneurial propensity does not affect entrepreneurial willingness.

Also, the correlation between Scandinavian social values and perceived control is significant but quite low. Thus, Hypothesis 3 is not valid, and Hypothesis 4 is only partially valid. The main results are collected in Figure 2.

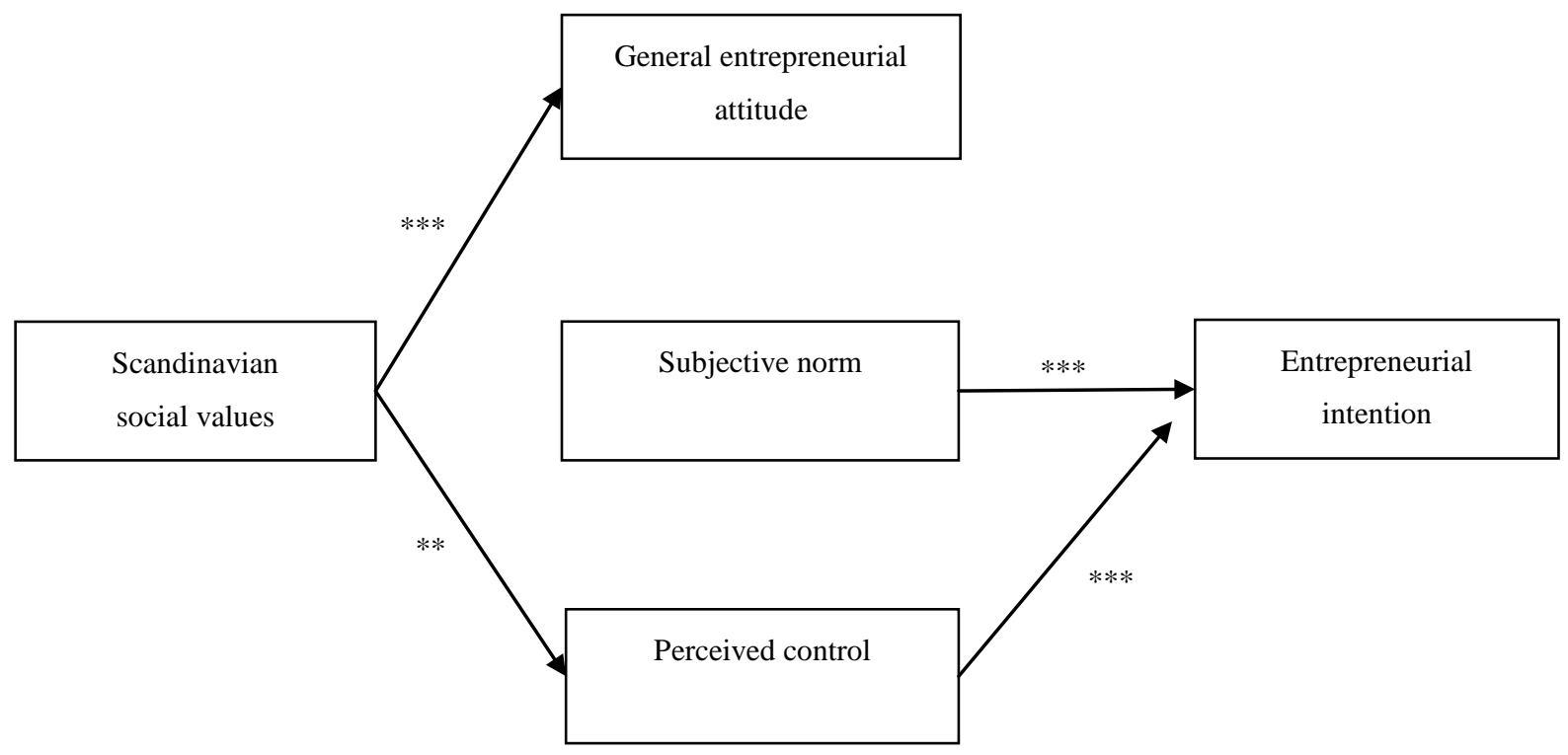

Figure 2. Significant dependencies between variables. Notes. ${ }^{* *} p<0.001 ; * * p<0.01$; $* p<0.05$.

\section{Conclusions and Discussions}

In this study, young people's attitudes and intentions towards entrepreneurship were examined. The results are in accordance with the theory of planned behavior. Social norms and perceived control were highly correlated with entrepreneurial intention. In contrast, entrepreneurial attitude does not explain entrepreneurial intention. The reason for this, of course, is that in this study it is general attitudes which are explained, not those 
specific attitudes towards personal entrepreneurial activities.

In general, it is assumed that individualism explains entrepreneurial attitudes (Lindsay, 2005), however in our study there is no correlation between social values and entrepreneurial intention. One possible interpretation is linked to the nature of Finnish individualism. Typically, horizontal individualism emphasizes equality and does not support competition in the same way as vertical individualism. In that sense, individualism in a Finnish form (horizontal individualism) does not encourage young people to make choices that support entrepreneurship.

According to the research results, it is possible to assume that entrepreneurship is a neutral issue among Finnish young people. Social values are connected with entrepreneurial attitude at a general level, but not at a practical level. A positive attitude towards entrepreneurship does not actualize as an entrepreneurial intention. Young people consider entrepreneurship first and foremost a pragmatic career option rather than an ideological choice (Patomäki, 2007).

Young people are committed to Scandinavian social values, which support the idea of horizontal individualism. Democratic rights and social justice have an important meaning for young people. These are values that create a kind of framework for individualism, and it is possible to implement horizontal individualism within this. On the other hand, however, young people share an idea of collectivism that is expressly defined as the state's responsibility for all citizens rather than an individual's commitment to joint liability. Thus, Scandinavian social values are not obstacles to (horizontal) individualism.

At a general level, the Scandinavian welfare state has two functions. On the one hand, the welfare state creates an infrastructure well developed for entrepreneurship, and a kind of safety net that allows for entrepreneurial risk taking. The economy of Finland has succeeded well in this dimension. On the other hand, in a society with economic and social security, there are fewer necessities for competition in economic arenas. As a result, young people have a lower willingness to choose entrepreneurship when compared with many other economically developed countries.

\section{References}

Ajzen, I. (1991). The theory planned behavior. Organizational Behavior and Human Decision Process, 50, $179-211$.

Ajzen, I., \& Fishbein, M. (2000). Attitudes and the attitude-behavior relation: Reasoned and automatic processes. European Review of Social Psychology, 11, 1-33.

Alestalo, M., \& Kuhnle, S. (1987). The Scandinavian route: Economic, social and political developments in Denmark, Norway and Sweden. In R. Erikson, J. E. Hansen, S. Ringen, \& H. Uusitalo (Eds.), The Scandinavian model: Welfare states and welfare research (pp. 3-38). New York and London: M.E. Sharpe.

Alestalo, M., Hort, S. E. O., \& Kuhnle, S. (2009). The Nordic model: Conditions, origins, outcomes, lessons. Hertie School of Governance, Working Papers 41.

Anttonen, A., \& Sipilä, J. (2012). Universalism in the British and Scandinavian social policy debates. In A. Anttonen, L. Häikiö, \& K. Stefansson (Eds.), Welfare state, universalism and diversity (pp. 16-41). Cheltenham: Edward Elgar.

Bandura, A. (1982). Self-efficacy mechanism in human agency. American Psychologist, 37, 122-147.

Covin, J. G., \& Slevin, D. P. (1991). A conceptual model of entrepreneurship as firm behavior. Entrepreneurship Theory \& Practice, 16(1), 7-25.

de Rosa, A. S. (1993). Social representations and attitudes: Problems of coherence between the theoretical definition and procedure of research. Papers on Social Representations-Textes sur les Représentations Sociales, 2(3), 1-192.

Eagly, A. H., \& Chaiken, S. (1993). The psychology of attitudes. Fort Worth, T.X.: Harcourt Brace Jovanovich.

Ervasti, H. (2012). Who hates the welfare state? Criticism of the welfare state in Europe. In H. Ervasti, J. G. Andersen, T. Fridberg, \& K. Ringdal (Eds.), The future of the welfare state: Social policy attitudes and social capital in Europe (pp. 231-248). Cheltenham: Edward Elgar. 
Ervasti, H., Fridberg, T., Hjerm, M., \& Ringdal, K. (2008). Conclusions: Nordic uniqueness, reality or myth? In H. Ervasti, T. Fridberg, M. Hjerm, \& K. Ringdal (Eds.), Nordic social attitudes in a European perspective (pp. 249-261). Cheltenham: Edward Elgar.

Esping-Andersen, G. (1990). The three worlds of welfare capitalism. Cambridge: Polity Press.

Fayolle, A., Gailly, B., \& Lassas-Clerc, N. (2006). Effect and counter-effect of entrepreneurship education and social context on student's intentions. Estudiosde Economia Aplicada, 24(2), 509-523.

Flash Eurobarometer 283. (2009). Entrepreneurship in the EU and beyond. Retrieved from http://ec.europa.eu/enterprise/policies/sme/facts-figures-analysis/eurobarometer/fl283_en.pdf

Gawel, A. (2011). Entrepreneurship and sustainability: Do they have anything in common? Working Papers 3/2011. Faculty of International Business and Economics, Poznan University of Economics.

Goethner, M., Obschonka, M., Silbereisen, R. K., \& Cantner, U. (2012). Scientists' transition to academic entrepreneurship: Economic and psychological determinants. Journal of Economic Psychology, 33, 628-364.

Helsingin kaupungin tilastokeskus. (2009). Nuorten koulutus Helsingissä. Tilastoja 38. Helsinki.

Hofstede, G. (1980). Motivation, leadership and organization: Do American theories apply abroad? Organizational Dynamics, 9(1), 42-63.

Hofstede Centre. (2013). What about Finland? Retrieved from http://geert-hofstede.com/finland.html

Jensen, C. (2008). Worlds of welfare services and transfers. Journal of European Social Policy, 18(2), 151-162.

Kivelä, P. (2002). Ammattikorkeakouluopiskelijoiden suhtautuminen yrittäjyyteen. Pirkanmaan ammattikorkeakoulun julkaisusarja A. Tutkimukset ja selvitykset. Nro 3. Tampere.

Kreiser, P., Marino, L., Weaver, K. M. (2001). Correlates of entrepreneurship: The impact of national culture on risk-taking and proactiveness in SMEs. University of Alabama, Department of Management and Marketing.

Krueger, N. F., Reilly, M. D., \& Carsrud, A. L. (2000). Competing models of entrepreneurial intentions. Journal of Business Venturing, 15, 411-432.

Kuivalainen, S., \& Niemelä, M. (2010). From universalism to selectivism: The ideational turn of the anti-poverty policies in Finland. Journal of European Social Policy, 20(3), 263-275.

Liñán, F. (2008). Skill and value perceptions: How do they affect entrepreneurial intentions? International Entrepreneurship and Management Journal, 4, 257-272.

Liñán, F., \& Chen, Y. W. (2009). Development and cross-cultural application of a specific instrument to measure entrepreneurial intentions. Entrepreneurship Theory and Practice, 33(3), 593-617.

Lindsay, N. J. (2005). Toward a cultural model of indigenous entrepreneurial attitude. Academy of Marketing Science Review, 5, 1-18.

Lumpkin, G. T., \& Dess, G. G. (1996). Clarifying the entrepreneurial orientation construct and linking it to performance. The Academy of Management Review, 21(1), 135-172.

Mueller, S. L., \& Thomas, A. S. (2000). Culture and entrepreneurial potential: A nine country study of locus of control and innovativeness. Journal of Business Venturing, 16, 51-75.

Muuri, A. (2008). Sosiaalipalveluja kaikille ja kaiken ikää? Tutkimus suomalaisten mielipiteistä ja kokemuksista sosiaalipalveluista sekä niiden suhteesta legitimiteettiin. Tutkimuksia 178. Helsinki: Stakes.

Paakkunainen, K. (2007). Alkaisinko yrittäjäksi? Tutkimus nuorten yrittäjyyspoliittisista kirjoituksista ja asenteista. Yksityisyrittäjäin Säätiö, Kerhokeskus, Koulutyön tuki ry, Nuorisotutkimusverkosto. Nuorisotutkimusseura.

Patomäki, H. (2007). Uusliberalismi Suomessa: Lyhyt historia ja tulevaisuuden vaihtoehdot. Helsinki: WSOY.

Potter, J., \& Wetherell, M. (1987). Discourse and social psychology: Beyond attitudes and behaviour. London: Sage.

Rantanen, T. (2013). Students' attitudes towards entrepreneurship in the Uusimaa region in Finland. Interdisciplinary Studies Journal. In press.

Rauch, D. (2007). Is there really a Scandinavian social service model? A comparison of childcare and elderlycare in six European countries. Acta Sociologica, 50(3), 249-269.

Singelis, T. M., Triandis, H. C., Bhawuk, D. P. S., \& Gelfand, M. J. (1995). Horizontal and vertical dimensions of individualism and collectivism: A theoretical and measurement refinement. Cross-Cultural Research, 29, 240-275.

Statistics Finland. (2013). Statistical databases. Retrieved from http://www.stat.fi

Stenholm, P., Heinonen, J., Kovalainen, A., \& Pukkinen, T. (2011). Global entrepreneurship monitor: Finnish 2010 report. Turku: University of Turku. 